\title{
Analysis of influencing factors of viral load in patients with high-risk human papillomavirus
}

Xuerong Lu', Tiantian Wang ${ }^{1}$, Youzhong Zhang ${ }^{2}$ and Yuzhen Liu ${ }^{1 *}$

\begin{abstract}
Background: High-risk human papillomavirus (HR-HPV) load is thought to be influenced by many factors, and the relationship between viral load and the degree of cervical lesion is controversial. This study explored the possible influencing factors of HR-HPV viral load in the uterine cervix.

Methods: A total of 605 women who needed colposcopic evaluation for abnormal cervical screening at the Affiliated Hospital of Weifang Medical University, China, between November 2017 and September 2018 were enrolled. Cervical specimens were collected from the endo- and ectocervix separately using two different cervical brushes. The hybrid capture II test was used to measure HR-HPV load. Age, histological severity, number of viral types, and area and location of cervical lesions were recorded. The correlations between viral load and influencing factors were analysed using univariate and multivariate analyses.
\end{abstract}

Results: HR-HPV load was positively correlated with age, histological severity, multiple HPV types and area of cervical lesions $(P<0.05)$. Viral load with the combination of endo- and ectocervical sampling was significantly higher than simple endocervical sampling $(P<0.001)$. Multivariate analysis showed that age, multiple HPV types and area of cervical lesions were independent factors for HR-HPV load with a combination of endo- and ectocervical sampling $(P<0.05)$. However, only age and area of cervical lesions were independent factors for viral load with simple endocervical sampling $(P<0.05)$. No significant association was found between viral load and lesion severity in multivariate analysis $(P>0.05)$.

Conclusion: HR-HPV load is influenced by age, histological severity, multiple viral types, area of cervical lesion and sampling methods. Age and area of cervical lesions are independent factors for viral load.

Keywords: Human papillomavirus, Viral load, Cervical intraepithelial lesion, Influential factor

\section{Background}

Cervical cancer is the second most common gynaecological cancer worldwide. It is well established that almost all precancerous and cancerous lesions of the cervix are caused by persistent oncogenic high-risk human papillomavirus (HR-HPV) infection. Therefore, HPV DNA testing was recently recommended as an alternative to cytology-based cervical cancer screening by the

*Correspondence: lyz0412@wfmc.edu.cn

${ }^{1}$ Department of Obstetrics and Gynaecology, Affiliated Hospital of Weifang Medical University, 2428 Yuhe Road, Weifang 261042, China Full list of author information is available at the end of the article
American updated screening guidelines [1]. However, it is less specific and has low positive predictive value, which is incapable of differentiating transient and persistent infections [2], resulting in excessive management of women with innocuous HPV infections [3]. Therefore, how to best triage HPV-positive women through secondary screening to identify those women with true precancerous lesions remains a pending issue in cervical cancer screening.

Many epidemiologic studies have provided strong and consistent evidence that persistent infection with HR-HPV is responsible for the development, maintenance and progression of cervical intraepithelial lesions original author(s) and the source, provide a link to the Creative Commons licence, and indicate if changes were made. The images or other third party material in this article are included in the article's Creative Commons licence, unless indicated otherwise in a credit line to the material. If material is not included in the article's Creative Commons licence and your intended use is not permitted by statutory regulation or exceeds the permitted use, you will need to obtain permission directly from the copyright holder. To view a copy of this licence, visit http://creativecommons.org/licenses/by/4.0/. The Creative Commons Public Domain Dedication waiver (http://creativeco mmons.org/publicdomain/zero/1.0/) applies to the data made available in this article, unless otherwise stated in a credit line to the data. 
(SILs) and cervical cancer $(\mathrm{CC})[4,5]$. Persistence may depend on certain characteristics, such as high viral load as a result of viral replication [5]. However, the relation between HR-HPV viral load and future risk of HSIL or $\mathrm{CC}$ is less certain. Many studies have reported that viral load increases with the elevation of disease severity [6,7], while others have not confirmed such an increased risk of disease progression [8]. High viral load has been found to be associated with the persistence of infection [5], which is an important event in HR-HPV-associated neoplastic progression $[4,5]$. Therefore, a high viral load may also be associated with the elevation of disease severity. However, another important event in HPV-associated neoplastic progression is deregulation of normal patterns of virus gene expression $[9,10]$. There appear to be multiple causes of deregulated HPV gene expression, and the most common cause in cervical cancer is integration of the virus genome into host chromosomes [10]. Integration of the viral genome, which disrupts the E1 and E2 genes and leads to increased expression of the E6 and E7 oncoproteins [10], results in viral life cycle termination and a reduction in the actual viral DNA copy number [11]. Furthermore, there are probably undetermined confounding factors influencing HR-HPV load [5, 12-14].

Based on the abovementioned findings, we aim to explore the possible influencing factors of HR-HPV viral load in the uterine cervix. The results of this study are expected to contribute to an understanding of the association of viral load and the severity of cervical lesions.

\section{Materials and methods \\ Study population}

All clinical samples in this study were organized using the Weifang Cervical Lesions Screening cohorts, Shandong, P. R. China. Detection of the $21 \mathrm{HPV}$ genotypes was performed by the HPV GenoArray Test Kit (HybriBio Ltd., China) before enrolment of patients. A total of 605 women who needed colposcopic evaluation for abnormal cervical screening at the Affiliated Hospital of Weifang Medical University, China, between November 2017 and September 2018 were enrolled. The inclusion criteria were as follows: (1) agreement to participate; (2) HR-HPV positivity; (3) indication for colposcopy [15]; (4) no hysterectomy; and (5) no pregnancy. Women with cervical lesions that were not completely visible (unsatisfactory colposcopy) were excluded (Fig. 1). In total, 273 women were eligible for the study. All participants signed an informed consent document before enrolment. Women's ages ranged from 21 to 63 years (38.4 \pm 9.0 years). Based on the number of HPV types in primary screening, women were divided into the following two groups: multiple HPV types (at least two or more genotypes of

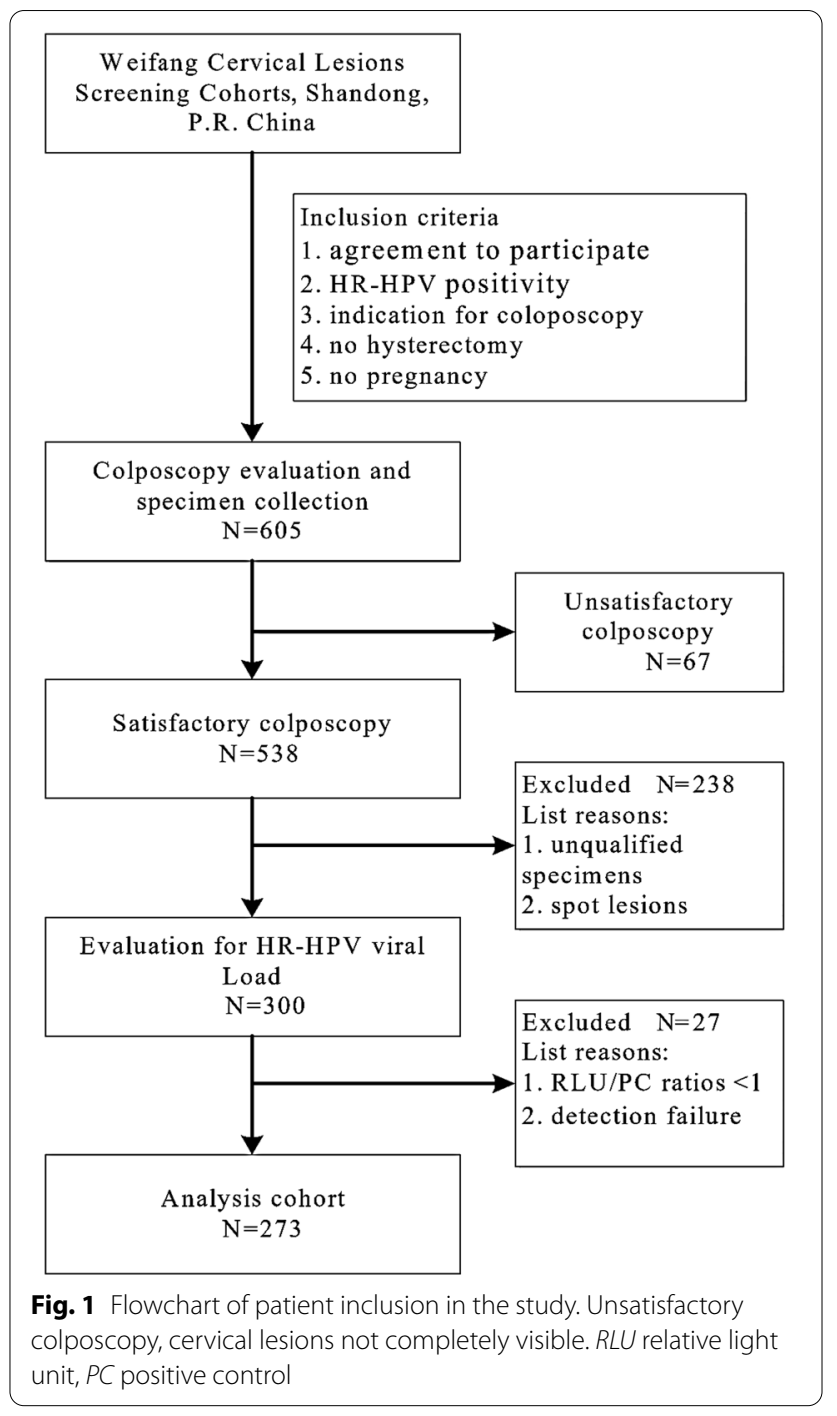

HR-HPV infection) and single HPV type (only one genotype of HR-HPV infection).

\section{Specimens collection}

At first, one physician (T. T. Wang) who was trained used a cytobrush (Digene Cervical Sampler, USA) to collect exfoliated cells from the endocervix (an area that can be covered by a cytobrush, bounded below by the ectocervix within a $0.5-\mathrm{cm}$ radius of the external orifice of the uterus). Then, a different cervical brush (ThinPrep ${ }^{\circledR}$ Cytologic Test Sampler, USA) was used to collect exfoliated cells of the ectocervix (an area that cannot be covered by a cytobrush bounded above by the ectocervix over a $0.5-\mathrm{cm}$ radius of the external orifice of the uterus). Both specimens were separately transferred to specimen preserving medium (formalin), stored at $-4{ }^{\circ} \mathrm{C}$ and sent to the laboratory for viral load testing 
using the commercially available Hybrid Capture II system (Digene, USA). Based on the anatomical sites of sampling, sampling methods were stratified into two groups: a simple endocervical sampling group and a combination of endo- and ectocervical sampling group.

\section{Colposcopic examination}

A standard colposcopic examination was performed by the same professional colposcopist (Y.Z. Liu). Cervical lesions showing aceto-white epithelium and/or atypical vessel changes (mosaic, punctation and tumour vessels) were measured under 15X magnification of colposcopy. The area $\left(\mathrm{cm}^{2}\right)$ and location (the distance between the external orifice of the uterus and the below bound of the lesions, $\mathrm{cm}$ ) of the lesions were quantified using a colposcopy image processor. Based on the location of lesions, women were stratified into two groups: involvement of the area bounded below by the ectocervix within a 0.5 $\mathrm{cm}$ radius of the external orifice of the uterus $(\leq 0.5)$ and involvement of the area bounded below by the ectocervix over a $0.5-\mathrm{cm}$ radius of the external orifice of the uterus $(>0.5)$. For pathology diagnosis, colposcopy with a directed biopsy was performed as indicated, and biopsy results were evaluated by two pathologists who were blind to the colposcopy results or clinical information. All cases with disagreement were reanalysed by another experienced pathologist. Based on colposcopy and pathology findings, the patients were stratified into three groups: negative (negative for intraepithelial lesion or malignancy), LSIL (low-grade squamous intraepithelial lesion), and HSIL/CC (high-grade squamous intraepithelial lesion and/or cervical cancer).

\section{Detection of HPV-DNA}

HPV genotyping by HybriMax was performed using an HPV GenoArray Test Kit (HybriBio Ltd., China). This assay can determine $21 \mathrm{HPV}$ types, including 14 highrisk HPV types $(16,18,31,33,35,39,45,51,52,56,58$, 59,66 , and 68), five low-risk HPV types $(6,11,42,43$, and 44), and two unknown-risk types (53 and CP8304), by the flow-through hybridization technique using HPV DNA amplified by PCR as described before [16].

A hybrid capture II assay (Digene, USA) was performed on cervical scrapings collected from the endo- and ectocervix (bounded by the $0.5-\mathrm{cm}$ radius of the external orifice of the uterus) separately using two different cervical brushes. Light measurements were quantified using a luminometer and were expressed by comparing the relative light units (RLU) of clinical samples with a positive control (PC). RLU/PC ratios (RLUs) were calculated as the ratio of the specimen luminescence to the luminescence of the $1.0 \mathrm{pg} / \mathrm{mL}$ HPV cut-off standard, which is known to represent a semiquantitative value for the cumulative viral burden of one or more of the 13 oncogenic HPV genotypes (types 16, 18, 31, 33, 35, 39, 45, 51, $52,56,58,59$ and 68). An RLU/PC ratio of 1 or higher was considered a positive result as proposed by the manufacturer (equivalent to $1 \mathrm{pg} / \mathrm{mL}$ of HPV-DNA).

\section{Statistical analysis}

All statistical analyses were performed using SPSS version 22.0 for Windows. Means, medians, ranges, standard deviations, 95\% confidence intervals, and standard errors of means were used as descriptive statistics. Viral load was measured as RLU/PC ratios (RLUs) and agreed with previous specifications in the hybrid capture assay. Viral quantification data in RLUs were initially continuous measurements. RLUs were transformed into their logarithm $(\log 10)$. An index of the Spearman correlation coefficient $\left(r_{\mathrm{s}}\right)$ was applied to measure the association between viral load and variables. Multiple linear regression analysis was applied to relate the viral load with variables. The variables included in the model were age, histological severity, number of HPV types, area and location of the cervical lesions. A paired $t$-test was used to compare viral load with different sampling methods. Two-tailed $P$ values less than 0.05 were considered statistically significant.

\section{Results}

\section{Correlation of HR-HPV load and age}

The median age of the 273 women was 39 years (range, 21-63 years). A significant association between viral load and age was found $\left(r_{\text {sendocervical }}=0.417, P_{\text {endocer- }}\right.$ vical $=0.001, \quad r_{\text {sendo-andectocervical }}=0.349, \quad P_{\text {endo-andectocer- }}$ vical $=0.001)$. A distinct upward trend of viral load paralleled increasing age (Table 1).

\section{Correlation of HR-HPV load and histological severity}

Based on the colposcopy and pathology findings, 90 of the women were pathologically negative, and 93 were diagnosed with LSIL, 72 with HSIL and 18 with CC. In the simple endocervical sampling method, there were marked increases in $\log _{10}$-transformed viral load $\left(\log _{10}\right.$ RLUs $)$ from the mean value of $0.79( \pm 0.39)$ in the pathologically negative group to $0.87( \pm 0.91)$ and $1.41( \pm 0.81)$ in the LSIL and HSIL/CC groups, respectively $\left(r_{\mathrm{s}}=0.371, P=0.002\right)$. Similarly, in combination with endo- and ectocervical sampling methods, distinct upward trends of $\log _{10}$-transformed viral load $\left(\log _{10}\right.$ RLUs) were observed from a mean value of 0.88 $( \pm 0.35)$ in the pathologically negative group to 1.03 $( \pm 0.89)$ and $1.66( \pm 0.70)$ in the LSIL and HSIL/CC groups, respectively $\left(r_{\mathrm{s}}=0.424, P<0.001\right)$ (Table 1$)$. 
Table 1 Univariate analysis of factors associated with HR-HPV load

\begin{tabular}{|c|c|c|c|c|c|c|c|c|}
\hline \multirow[t]{2}{*}{ Variables } & \multirow[t]{2}{*}{ Parameters } & \multirow{2}{*}{$\begin{array}{l}\text { Number } \\
\text { of patients } \\
\text { (\%) }\end{array}$} & \multicolumn{3}{|c|}{ Simple endocervical sampling } & \multicolumn{3}{|c|}{$\begin{array}{l}\text { Combination of endo-and ectocervical } \\
\text { sampling }\end{array}$} \\
\hline & & & $\begin{array}{l}\text { Mean (SD) of } \log _{10} \\
\text { transformed viral } \\
\text { load }\end{array}$ & $r_{\mathrm{s}}$-value ${ }^{\mathrm{a}}$ & $P$-value & $\begin{array}{l}\text { Mean }(S D) \text { of } \log _{10} \\
\text { transformed viral } \\
\text { load }\end{array}$ & $r_{\mathrm{s}}$-value ${ }^{\mathrm{a}}$ & $P$-value \\
\hline \multirow[t]{5}{*}{ Age (years) } & $20-29$ & $52(19.0)$ & $0.57( \pm 0.62)$ & 0.417 & 0.001 & $0.76( \pm 0.61)$ & 0.349 & 0.001 \\
\hline & $30-39$ & $91(33.3)$ & $0.92( \pm 0.73)$ & & & $1.11( \pm 0.67)$ & & \\
\hline & $40-49$ & $99(36.3)$ & $1.16( \pm 0.78)$ & & & $1.29( \pm 0.78)$ & & \\
\hline & $50-59$ & $25(9.2)$ & $1.41( \pm 0.69)$ & & & $1.63( \pm 0.72)$ & & \\
\hline & $60-69$ & $6(2.2)$ & $2.52( \pm 0.13)$ & & & $2.56( \pm 0.17)$ & & \\
\hline \multirow[t]{3}{*}{ Lesion severity } & Negative & $90(33.0)$ & $0.79( \pm 0.39)$ & 0.371 & 0.002 & $0.88( \pm 0.35)$ & 0.424 & $<0.001$ \\
\hline & LSIL & $93(34.1)$ & $0.87( \pm 0.91)$ & & & $1.03( \pm 0.89)$ & & \\
\hline & $\mathrm{HSIL} / \mathrm{CC}$ & $90(33.0)$ & $1.41( \pm 0.81)$ & & & $1.66( \pm 0.70)$ & & \\
\hline \multirow[t]{2}{*}{ Multiple HPV types } & No & $200(73.3)$ & $0.92( \pm 0.71)$ & 0.198 & 0.060 & $1.08( \pm 0.65)$ & 0.237 & 0.024 \\
\hline & Yes & $73(26.7)$ & $1.29( \pm 0.93)$ & & & $1.48( \pm 0.95)$ & & \\
\hline \multirow[t]{7}{*}{ Area of lesions $\left(\mathrm{cm}^{2}\right)$} & $0.0-0.49$ & $174(63.7)$ & $0.95( \pm 0.74)$ & 0.292 & 0.017 & $1.04( \pm 0.70)$ & 0.364 & $<0.001$ \\
\hline & $0.5-0.99$ & $46(16.8)$ & $1.03( \pm 0.72)$ & & & $1.22( \pm 0.69)$ & & \\
\hline & $1.0-1.49$ & $24(8.8)$ & $0.93( \pm 0.82)$ & & & $1.41( \pm 0.75)$ & & \\
\hline & $1.5-1.99$ & $6(2.2)$ & $1.64( \pm 0.94)$ & & & $1.80( \pm 0.77)$ & & \\
\hline & $2.0-2.49$ & $10(3.7)$ & $1.76( \pm 0.86)$ & & & $1.90( \pm 0.73)$ & & \\
\hline & $2.5-2.99$ & $7(2.6)$ & $0.27( \pm 0.14)$ & & & $0.72( \pm 0.01)$ & & \\
\hline & $3.0-3.49$ & $6(2.2)$ & $2.43( \pm 0.41)$ & & & $2.89( \pm 0.06)$ & & \\
\hline \multirow[t]{2}{*}{ Location of lesions (cm) } & $\leq 0.5$ & $125(68.3)$ & $1.05( \pm 0.72)$ & -0.017 & 0.891 & $1.21( \pm 0.65)$ & -0.129 & 0.222 \\
\hline & $>0.5$ & $58(31.7)$ & $0.90( \pm 1.01)$ & & & $1.10( \pm 1.09)$ & & \\
\hline
\end{tabular}

Negative negative for intraepithelial lesion or malignancy, LSIL low-grade squamous intraepithelial lesion, HSIL/CC high-grade squamous intraepithelial lesion and/or cervical cancer

a Spearman correlation coefficient. SD, standard deviation. Location of lesions, the distance between the external orifice of the uterus and the below bound of the lesions. $\leq 0.5 \mathrm{~cm}$, involvement of the area bounded below by the ectocervix within a $0.5-\mathrm{cm}$ radius of the external orifice of the uterus; $>0.5 \mathrm{~cm}$, involvement of the area bounded below by the ectocervix over a $0.5-\mathrm{cm}$ radius of the external orifice of the uterus. Multiple HPV types, at least two or more genotypes of HR-HPV infection

\section{Correlation of HR-HPV load and multiple HPV types}

In this population, $73.3 \%(200 / 273)$ of the women were positive for a single viral type. A total of $26.7 \%$ (73/273) were positive for multiple viral types. In the simple endocervical sampling method, no significant association between viral load and multiple HPV types was found $\left(r_{\mathrm{s}}=0.198, P=0.060\right)$. In the combination of endo- and ectocervical sampling methods, the multiple HPV type infection group showed a significantly higher viral load than the single HPV type infection group $\left(r_{\mathrm{s}}=0.237, P=0.024\right)$ (Table 1$)$.

\section{Correlation of HR-HPV load and area of cervical lesions}

Viral load was significantly associated with the area of the cervical lesions $\left(r_{\text {sendocervical }}=0.292, P\right.$ endocervical $=0.017, \quad r_{\text {sendo-andectocervical }}=0.364, \quad P_{\text {endo-andectocer- }}$ vical $<0.001)$. A distinct upward trend of viral load paralleled the increasing area of cervical lesions (Table 1).

\section{Correlation of HR-HPV viral load and location of cervical lesions}

Among the 183 women with colposcopy-detectable cervical lesions, there were 125 and 58 cases with lesions involving the area bounded below by the ectocervix within a $0.5-\mathrm{cm}$ radius $(\leq 0.5)$ and bounded below by the ectocervix over a $0.5-\mathrm{cm}$ radius $(>0.5)$ of the external orifice of uterus, respectively. No statistical association was identified between viral load and location of the cervical lesions $\left(r_{\text {sendocervical }}=-0.017, P_{\text {endocervical }}=0.891\right.$, $\left.r_{\text {sendo-andectocervical }}=-0.129, \quad P_{\text {endo-andectocervical }}=0.222\right)$ (Table 1).

\section{Correlation of HR-HPV load and sampling methods}

The value of $\log _{10}$-transformed viral load ( $\log _{10} R L U s$ ) showed a significant difference between simple endocervical sampling and the combination of endo- and ectocervical sampling $(1.19 \pm 0.76$ vs. $1.02 \pm 0.790)$. Viral load with the combination of endo- and ectocervical sampling 
Table 2 Comparison of HR-HPV load between simple endocervical sampling and combination of endo- and ectocervical sampling

\begin{tabular}{|c|c|c|c|c|c|}
\hline Sampling method & Simple endocervical sampling & $\begin{array}{l}\text { Combination of endo- } \\
\text { and ectocervical sampling }\end{array}$ & $95 \% \mathrm{Cl}$ & $t$-value ${ }^{a}$ & $P$-value \\
\hline $\begin{array}{l}\text { Mean(SD) of } \log _{10} \text { transformed viral } \\
\text { load }\end{array}$ & $1.02( \pm 0.79)$ & $1.19( \pm 0.76)$ & $0.130-0.197$ & 9.67 & $<0.001$ \\
\hline
\end{tabular}

Table 3 Multivariate analysis of factors associated with HR-HPV load in simple endocervical sampling

\begin{tabular}{|c|c|c|c|c|c|}
\hline \multirow[t]{2}{*}{ Variables } & \multicolumn{2}{|c|}{$\begin{array}{l}\text { Unstandardized } \\
\text { coefficients }\end{array}$} & \multirow{2}{*}{$\begin{array}{l}\text { Standardised } \\
\text { coefficients } \\
\beta \text { value }\end{array}$} & \multirow[t]{2}{*}{$t$-value ${ }^{a}$} & \multirow[t]{2}{*}{$P$-value } \\
\hline & $\beta$ value & $S E$ & & & \\
\hline Age & 4.695 & 1.316 & 0.376 & 3.567 & 0.001 \\
\hline Lesion severity & 9.441 & 19.213 & 0.062 & 0.491 & 0.625 \\
\hline Area of lesions & 46.615 & 17.525 & 0.339 & 2.660 & 0.010 \\
\hline
\end{tabular}

SE standard error

${ }^{a}$ Multiple linear regression analysis

Table 4 Multivariate analysis of factors associated with HR-HPV load in combination of endoand ectocervical sampling

\begin{tabular}{|c|c|c|c|c|c|}
\hline \multirow[t]{2}{*}{ Variables } & \multicolumn{2}{|c|}{$\begin{array}{l}\text { Unstandardized } \\
\text { coefficients }\end{array}$} & \multirow{2}{*}{$\begin{array}{l}\text { Standardised } \\
\text { coefficients } \\
\beta \text { value }\end{array}$} & \multirow[t]{2}{*}{$t$-value ${ }^{a}$} & \multirow[t]{2}{*}{$P$-value } \\
\hline & $\beta$ value & $S E$ & & & \\
\hline Age & 4.181 & 1.399 & 0.252 & 2.990 & 0.004 \\
\hline Lesion severity & 10.878 & 18.841 & 0.059 & 0.577 & 0.565 \\
\hline $\begin{array}{l}\text { Multiple HPV } \\
\text { types }\end{array}$ & 72.833 & 27.984 & 0.219 & 2.603 & 0.011 \\
\hline Area of lesions & 96.290 & 20.641 & 0.480 & 4.665 & $<0.001$ \\
\hline
\end{tabular}

SE standard error

${ }^{a}$ Multiple linear regression analysis

was significantly higher than with simple endocervical sampling $(t=9.67, P<0.001)$ (Table 2$)$.

\section{Multivariate analysis for viral load}

All the variables were included and were found to be significant according to univariate analysis in the present study. In simple endocervical sampling, this analysis showed that only age and area of cervical lesions were independent influencing factors for HR-HPV load $\left(P_{\text {age }}=0.001, P_{\text {areaoflesions }}=0.010\right)$. In combination with endo- and ectocervical sampling methods, this analysis found that age, multiple HPV types, and area of cervical lesions were independent influencing factors for
HR-HPV load $\left(P_{\text {age }}=0.004, P_{\text {multipleHPVtypes }}=0.011, P_{\text {areao- }}\right.$ flesions $<0.001)$ (Tables 3, 4).

\section{Discussion}

Persistent high-risk human papillomavirus (HR-HPV) infection is the main cause of precancerous and cancerous lesions of the cervix $[4,5]$. Viral load reflects the number of infected cells and viral copies in individual cells. High viral load has been suggested as a marker of nontransient infection [5]. Therefore, a high viral load may also be associated with the progression of cervical lesions. However, the association between HPV viral load and cervical lesion grade is controversial. There could be undetermined confounding factors, such as age, number of viral types, area and location of cervical lesions $[5,12-14]$. Few studies have incorporated these factors into the analysis, so the influence of confounding factors cannot be excluded. In the present study, we conducted a multiple linear regression analysis to evaluate factors associated with HR-HPV load. To analyse the influence of sampling factors on viral load, two different sampling methods were used to obtain cervical specimens for viral load detection. The aim of this study was to explore the possible influencing factors of viral load.

In this study, the results showed that age was an independent factor for HR-HPV load and that a significantly increasing age correlated with a higher viral load. This result agrees with previous population-based studies [17, 18], which showed that HR-HPV load was higher in older age. Different from previous studies, this study incorporated different variables into the analysis to adjust the effect of confounding factors and showed that age was an independent factor for HR-HPV load. However, contrary to our finding, Flores $\mathrm{R}$ et al. reported that HR-HPV load declined with age and was significantly higher in younger women [19]. They divided women into three age groups (15-24, 25-32, 32-79 years) and found that younger women presented higher viral load. This observation is understandable, and the effect of age on viral load is probably related to the balance between new acquisition of HR-HPV infections and viral clearance. Young women $(<25$ years old) may represent new exposures to 
HPV due to sexual debut when an immune response to HPV has not yet been established. Therefore, the rate of new acquisition of HR-HPV infections exceeds the clearance rate [20], favouring the rapid accumulation of infections, which might contribute to a high viral load at an early age. Older women ( $>45$ years old) are more likely to experience physiological and immunological disorders during the menopausal transition. Such physiologic and immunologic dysregulation can result in an inability to establish an immune response to HPV, and a high level of HPV infections cannot achieve spontaneous clearance $[13,21]$.

Several studies have reported the association of high viral load with the risk for cervical cancer and its precursors. A large number of studies used the Hybrid Capture II assay to measure viral load, and while some found viral load to be positively associated with increased severity of cervical lesions [6, 7], others did not [8]. Different from previous studies, the present study explored the relationship between HR-HPV load and cervical lesion severity when other cofactors were taken into consideration. In agreement with some investigators [6, 7], this study showed a positive association between cervical lesion severity and viral load. However, this association lost significance when other cofactors, including age, presence of multiple HR-HPV infections and area of cervical lesions, were considered in multivariate analysis. This fact could be explained by the bias of Hybrid Capture II viral load. One major bias is that this test does not provide an evaluation of cell numbers, which vary substantially with different areas of cervical lesions. Moreover, high viral load detected by Hybrid Capture II may represent single or multiple HPV types among the 13 high-risk types detected by the kit, but this test does not provide the evaluation of the number of HR-HPV types. Therefore, these factors (area and presence of multiple HRHPV infections) may confound the association between HR-HPV load and cervical lesion severity. Therefore, HRHPV load determined by Hybrid Capture II alone may not be used as a molecular biomarker of risk for developing cervical (pre-) cancerous lesions.

The prevalence rate of concurrent multiple HPV genotype infections was reported to be approximately $20 \%$ $25 \%$ in several large studies [22, 23], which was nearly consistent with our result (26.7\%). The role of multiple infections in carcinogenesis, with synergistic or antagonistic effects, remains to be determined [24, 25], although some studies have considered them to be a risk factor for HPV persistence and for preinvasive and invasive cervical lesions [24]. In this study, we analysed the correlation between multiple HPV genotype infections and HR-HPV load, which was calculated by two sampling methods, when possible confounding factors were incorporated into the analysis. The data indicated that multiple HPV genotype infections presented with significantly higher viral loads than single HPV genotype infections, but not significantly so in the simple endocervical sampling method, probably due to the impact of sampling variation on viral load and the relatively small-scale population. This finding indicates that cervical lesions induced by multiple HPV genotype infections are more likely to be associated with increased viral copies.

Current data showed that a distinct upward trend of viral load paralleled the increasing area of cervical lesions in both univariate and multivariate analyses. This result corroborates previous studies that have reported that more severe lesions tended to be larger and to harbour more HPV viral copies [26-28]. Different from previous studies, this study incorporated different variables into the analysis to adjust for the effects of confounding factors and showed that the area of cervical lesions is an independent factor determining viral load. This finding indicates that viral load is strongly affected by the number of infected cells, which increases in parallel with the increasing area of squamous intraepithelial lesions. However, to explore the association between HPV viral load and cervical lesion grade, some studies normalized viral load by using human cells to adjust the absolute viral load (e.g., expressed by copies/10,000 cells) to lessen the impact of the variation of sample volume [29]. This may lead to ignoring the effect of the number of infected cells on viral load.

HPV viral load estimated from cervical scrapings can be easily affected by sampling [14]. The radius of the cytobrush, such as a Digene cervical sampler, which is commonly used in HPV tests, is $0.5 \mathrm{~cm}$. It is limited to collecting specimens in the area of the external orifice of the uterus within a $0.5-\mathrm{cm}$ radius. When cervical lesions extend to the area of the external orifice of the uterus over a $0.5-\mathrm{cm}$ radius, the brush cannot fully reach them, resulting in the collection of an inadequate number of cells that would underestimate the actual viral load. Therefore, to evaluate the impact of sampling methods on viral load, we compared the currently used simple endocervical sampling method with a new method of a combination of endo- and ectocervical sampling. We found that the viral load with a combination of endo- and ectocervical sampling was significantly higher than that with simple endocervical sampling. However, there was no significant difference in viral load between the lesions located in the area of the external orifice of the uterus within and over a $0.5-\mathrm{cm}$ radius. This may be explained by a possible biased selection of participants in our study, in that only a minor proportion of the enrolled women with cervical lesions involved the area of the external orifice of the uterus over a $0.5-\mathrm{cm}$ radius. 
To our knowledge, our study is the first to demonstrate that age and area of cervical lesions are independent factors determining viral load, which may contribute valuable data for future discussions related to the potential application of viral load measurement. Nevertheless, several limitations also need to be addressed. First, the number of women with cervical lesions involving the area of the external orifice of the uterus over a $0.5-\mathrm{cm}$ radius is too limited to draw a definitive conclusion for the effect of location of the cervical lesions on viral load and specimen collection methods. In addition, clinical data collected in one institution limit our statistical power to draw definitive conclusions for populations worldwide. Finally, the sample size in our study hinders our capacity to evaluate the association of HR-HPV load with other potential confounders, such as sampling physicians and individual HPV types. Further intensive clinical setup and laboratory investigations are therefore needed.

\section{Conclusion}

High-risk human papillomavirus (HR-HPV) load is influenced by age, histological severity, multiple viral types, area of cervical lesions and sampling methods. Age and area of cervical lesions are independent factors for viral load. Comprehensive sampling is needed, especially when the cervical lesions are located far from the cervical orifice of the uterus.

\begin{abstract}
Abbreviations
LSIL: Low-grade squamous intraepithelial lesion; HSIL: High-grade squamous intraepithelial lesion; CC: Cervical cancer; HR-HPV: High-risk-Human papillomavirus; HCll: Hybrid capture II; TCT: Thinprep cytological test; HPV-DNA: Human papillomavirus deoxyribonucleic acid; ASC-US: Atypical squamous cell of undetermined significance; RLU: Relative light units; PC: Positive control.
\end{abstract}

\section{Acknowledgements}

The authors would also like to thank Dr. Hongqing, Liu and Mrs. Antong, Fan (Department of Epidemiology and Health statistics, Weifang Medical University, Weifang, China) for data analysis and interpretation.

\section{Authors' contributions \\ YZL designed the study. TTW, XRL and YZL designed and performed the experiments. XRL verified and analyzed the data, and wrote the manuscript. YZL and YZZ edited the manuscript. All authors read and approved the final manuscript.}

\section{Funding}

This study was supported by a grant from the National Natural Science Fund of China (No. 81572559) and Scientific Research Foundation of the Weifang Medical University (2017BSQD43).

\section{Availability of data and materials}

The data used to support the findings of this study are mainly included within the article, and the underlying data are available from the corresponding author upon request.

\section{Ethics approval and consent to participate}

Ethics approval is not applicable. Informed consent was obtained from each participant.
Consent for publication

Not applicable.

\section{Competing interests}

The authors declare that they have no competing interests.

\section{Author details}

${ }^{1}$ Department of Obstetrics and Gynaecology, Affiliated Hospital of Weifang Medical University, 2428 Yuhe Road, Weifang 261042, China. ${ }^{2}$ Department of Obstetrics and Gynaecology, Qilu Hospital, Shandong University, Jinan, China.

Received: 6 May 2020 Accepted: 21 December 2020

Published online: 06 January 2021

\section{References}

1. Huh WK, Ault KA, Chelmow D, Davey DD, Goulart RA, Garcia FA, et al. Use of primary high-risk human papillomavirus testing for cervical cancer screening: interim clinical guidance. Obstet Gynecol. 2015;125:330-7.

2. Zhao X, Wu Q, Wang X, Fu Y, Zhang X, Tian X, et al. The performance of human papillomavirus DNA detection with type 16/18 genotyping by hybrid capture in primary test of cervical cancer screening: a cross-sectional study in 10, 669 Chinese women. Clin Microbiol Infect. 2018;24(12):1322-7.

3. Torres-Ibarra L, Lazcano-Ponce E, Franco EL, Cuzick J, Hernández-Ávila M, Lorincz A, et al. Triage strategies in cervical cancer detection in Mexico: methods of the FRIDA Study. Salud pública de México. 2016;58:197-210.

4. Kjaer SK, van den Brule AJ, Paull G, Svare El, Sherman ME, Thomsen BL, et al. Type specific persistence of high risk human papillomavirus (HPV) as indicator of high grade cervical squamous intraepithelial lesions in young women: population based prospective follow up study. BMJ. 2002;325:572.

5. Dalstein V, Riethmuller D, Prétet JL, Le Bail CK, Sautière JL, Carbillet JP, et al. Persistence and load of high-risk HPV are predictors for development of high-grade cervical lesions: a longitudinal French cohort study. Int J Cancer. 2003;106:396-403.

6. Dong L, Wang MZ, Zhao XL, Feng RM, Hu SY, Zhang Q, et al. Human papillomavirus viral load as a useful triage tool for non-16/18 high-risk human papillomavirus positive women: a prospective screening cohort study. Gynecol Oncol. 2018;148:103-10.

7. Luo H, Belinson JL, Du H, Liu Z, Zhang L, Wang C, et al. Evaluation of viral load as a triage strategy with primary high-risk human papillomavirus cervical cancer screening. J Low Genit Tract Dis. 2017;21:12-6.

8. Del Río-Ospina L, Soto-De León SC, Camargo M, Moreno-Pérez DA, Sánchez R, Pérez-Prados A, et al. The DNA load of six high-risk human papillomavirus types and its association with cervical lesions. BMC Cancer. 2015;15:100.

9. Groves IJ, Coleman N. Pathogenesis of human papillomavirus-associated mucosal disease. J Pathol. 2015;235:527-38.

10. Pett M, Coleman N. Integration of high-risk human papillomavirus: a key event in cervical carcinogenesis? J Pathol. 2007;212:356-67.

11. Ganguly N, Parihar SP. Human papillomavirus E6 and E7 oncoproteins as risk factors for tumorigenesis. J Biosci. 2009;34:113-23.

12. Sherman ME, Wang SS, Wheeler CM, Rich L, Gravitt PE, Tarone R, et al. Determinants of human papillomavirus load among women with histological cervical intraepithelial neoplasia 3: dominant impact of surrounding low-grade lesions. Cancer Epidemiol Biomarkers Prev. 2003;12:1038-44.

13. Li W, Meng Y, Wang Y, Cheng X, Wang C, Xiao S, et al. Association of age and viral factors with high-risk HPV persistence: a retrospective follow-up study. Gynecologiconcology. 2019;154:345-53.

14. Deng T, Feng Y, Zheng J, Huang Q, Liu J. Low initial human papillomavirus viral load may indicate worse prognosis in patients with cervical carcinoma treated with surgery. J Gynecol Oncol. 2015;26:111-7.

15. Massad LS, Einstein MH, Huh WK, Katki HA, Kinney WK, Schiffman M, et al. 2012 updated consensus guidelines for the management of abnormal cervical cancer screening tests and cancer precursors. Obstet Gynecol. 2013;121:829-46. 
16. Tao P, Zheng W, Wang Y. Sensitive HPV genotyping based on the flow-through hybridization and gene chip. J Biomed Biotechnol. 2012;2012:938780.

17. Hernández-Hernández DM, Ornelas-Bernal L, Guido-Jiménez M, ApresaGarcia T, Alvarado-Cabrero I, Salcedo-Vargas M, et al. Association between high-risk human papillomavirus DNA load and precursor lesions of cervical cancer in Mexican women. Gynecol Oncol. 2003;90:310-7.

18. Syrjänen K, Kulmala SM, Shabalova I, Petrovichev N, Kozachenko V, Zakharova T, et al. Epidemiological, clinical and viral determinants of the increased prevalence of high-risk human papillomavirus (HPV) infections in elderly women. Eur J Gynaecol Oncol. 2008;29:114-22.

19. Flores R, Papenfuss M, Klimecki WT, Giuliano AR. Cross-sectional analysis of oncogenic HPV viral load and cervical intraepithelial neoplasia. Int J Cancer. 2006;118:1187-93.

20. Syrjänen S, Shabalova I, Petrovichev N, Podistov J, Ivanchenko O, Zakharenko S, et al. Age-specific incidence and clearance of high-risk human papillomavirus infections in women in the former Soviet Union. Int J STD AIDS. 2005:16:217-23.

21. Althoff KN, Paul P, Burke AE, Viscidi R, Sangaramoorthy M, Gravitt PE. Correlates of cervicovaginal human papillomavirus detection in perimenopausal women. J Womens Health (Larchmt). 2009;18:1341-6.

22. Dong B, Sun P, Ruan G, Huang W, Mao X, Kang Y, et al. Type-specific high-risk human papillomavirus viral load as a viable triage indicator for high-grade squamous intraepithelial lesion: a nested case- control study. Cancer Manag Res. 2018;10:4839-51.

23. Wang S, Wei H, Wang N, Zhang S, Zhang Y, Ruan Q, et al. The prevalence and role of human papillomavirus genotypes in primary cervical screening in the northeast of China. BMC Cancer. 2012;12:160.
24. Sasagawa T, Basha W, Yamazaki H, Inoue M. High-risk and multiple human papillomavirus infections associated with cervical abnormalities in Japanese women. Cancer Epidemiol Biomark Prev. 2001;10:45-52.

25. Chaturvedi AK, Myers L, Hammons AF, Clark RA, Dunlap K, Kissinger PJ, et al. Prevalence and clustering patterns of human papillomavirus genotypes in multiple infections. Cancer Epidemiol Biomark Prev. 2005; 14:2439-45.

26. Sun CA, Lai HC, Chang CC, Neih S, Yu CP, Chu TY. The significance of human papillomavirus viral load in prediction of histologic severity and size of squamous intraepithelial lesions of the uterine cervix. Gynecol Oncol. 2001;83(1):95-9.

27. Crum CP, Nagai N, Levine RU. In situ hybridization analysis of HPV 16 DNA sequences in early cervical neoplasia. Am J Pathol. 1986;123(1):174-82.

28. Schneider A, Oltersdorf T, Schneider V. Distribution pattern of human papilloma virus 16 genome in cervical neoplasia by molecular in situ hybridization of tissue sections. Int J Cancer. 1987;9(6):717-21.

29. Segondy M, Ngou J, Kelly H, Omar T, Goumbri-Lompo O, Doutre S, et al. Diagnostic value of human papillomavirus (HPV) 16 and HPV 18 viral loads for the detection of high-grade cervical intraepithelial neoplasia (CIN2+) in a cohort of African women living with HIV. J Clin Virol. 2018;100:9979-83.

\section{Publisher's Note}

Springer Nature remains neutral with regard to jurisdictional claims in published maps and institutional affiliations.
Ready to submit your research? Choose BMC and benefit from:

- fast, convenient online submission

- thorough peer review by experienced researchers in your field

- rapid publication on acceptance

- support for research data, including large and complex data types

- gold Open Access which fosters wider collaboration and increased citations

- maximum visibility for your research: over 100M website views per year

At BMC, research is always in progress.

Learn more biomedcentral.com/submissions 